\title{
APLIKASI TECHNOPRENEURSHIP UNTUK MENGEMBANGKAN INDUSTRI KECIL MELALUI PENGGUNAAN TEKNOLOGI E-COMMERCE BERBASIS CONTENT MANAGEMENT SYSTEM Studi Kasus Pada UKM Mandiri Gypsum
}

\author{
Ahmad Muhsin \\ Program Studi Teknik Industri, Fakultas Teknologi Industri \\ UPN "Veteran" Yogyakarta \\ Jl. Babarsari 2 Tambakbayan Yogyakarta 55281 \\ email : ahmad.muhsin@upnyk.ac.id
}

\begin{abstract}
Central Bureau of Statistics catalog of DIY Province in the book BPS : 1102001.34 " DIY Yearbook " in 2009 in the field of Industrial, Energy, and Construction said that the total number of SMEs in the DIY business units with as many as 18367 division business areas include : food processing, clothing and skin, chemicals and building materials, craft and general, and metals and services. Data obtained through the SME Database Official web Disperindagkop obtained data for DIY types there are only 3 Gypsum SME business unit. While the survey states that in some industries Gypsum Gypsum today began much-loved community because it has the impression of a clean, luxurious, and provide a cool atmosphere in addition to its affordability. For that we need we need a more effective means to introduce the public to Gypsum to further develop this business. UPN "Veteran "Yogyakarta is one of the academicians who have set Technopreneurship as compulsory subjects that must be taken by students. Technopreneurship into a technology -based business incubator, which serves to cultivate the entrepreneurial spirit. The new breakthrough strategies to anticipate that the intellectual problem of unemployment is increasing. The difference with entrepreneurship lies in the application of technology in entrepreneurial business processes. This study aims to apply Technoprenurship in the real industry that serves to bridge the needs of Small Industrial Technology needs to help increase their business productivity. Media used in the technology packaged e-commerce website to complete the requirements of business processes based on ICT (Information Communication Technology). Online stores are made in this study to apply technology -based Information System Content Management System. E-commerce site aims to produce a site that is automatically able to introduce a small industry online, can reach various regions throughout the world, and capable of operating for 24 hours nonstop. Technology Content Management System chosen for ease of operation and ease of communication between managers and consumers. The results of this study resulted in an e-commerce website that can be accessed in www.gypsumnatural.com, Implementation Based Technopreneurship Curicullum on this site to provide an alternative marketing through the Information Technology field, provide ease of communication, and expand access to build a networking business world.
\end{abstract}

Keywords : e-commerce, Technopreneurship, Content Management System, Website

Badan Pusat Statistik Provisinsi DIY dalam buku katalog BPS : 1102001.34 "DIY Dalam Angka " tahun 2009 dalam bidang Industri, Energi, dan Konstruksi menyebutkan bahwa jumlah total IKM di DIY sebanyak 18.367 unit usaha dengan pembagian bidang usaha meliputi : pengolahan pangan, sandang dan kulit, kimia dan bahan bangunan, kerajinan dan umum, dan logam dan jasa. Data yang diperoleh melalui web Resmi Database IKM Disperindagkop DIY diperoleh data untuk jenis IKM Gypsum hanya ada 3 unit usaha. Sementara hasil survey dibeberapa industri Gypsum menyebutkan bahwa Gypsum saat ini mulai banyak digemari masyarakat karena memiliki kesan bersih, mewah, dan memberikan suasana dingin disamping harganya yang terjangkau. Untuk itu perlu diperlukan sebuah sarana yang lebih efektif untuk memperkenalkan Gypsum ke masyarakat agar usaha ini lebih berkembang. UPN "Veteran" Yogyakarta adalah salah satu sivitas akademika yang telah menetapkan Technopreneurship sebagai matakuliah wajib yang harus ditempuh oleh mahasiswanya. Technopreneurship menjadi sebuah inkubator bisnis berbasis teknologi, yang berfungsi untuk menumbuh kembangkan jiwa kewirausahaan. Strategi terobosan baru untuk mensiasati masalah pengangguran intelektual yang semakin 
meningkat. Perbedaan dengan entrepreneurship terletak pada penerapan teknologi dalam proses bisnis wirausaha. Penelitian ini bertujuan untuk menerapkan Technoprenurship di dalam industri nyata yang berfungsi menjembatani kebutuhan Industri Kecil terhadap kebutuhan Teknologi dalam membantu meningkatkan produktivitas usahanya. Media yang digunakan dikemas dalam teknologi website e-commerce untuk menyelesaikan kebutuhan proses bisnis berbasis ICT (Information Communication Technology). Toko Online yang dibuat dalam penelitian ini mengaplikasikan teknologi Sistem Informasi berbasis Content Management System. Situs e-commerce bertujuan untuk menghasilkan situs yang secara otomatis mampu memperkenalkan industry kecil secara online, dapat menjangkau berbagai wilayah diseluruh dunia, dan mampu beroperasi selama 24 jam nonstop. Teknologi Content Management System dipilih untuk memudahkan dalam pengoperasian dan memudahkan komunikasi antara pengelola dan konsumen. Hasil penelitian ini menghasilkan situs e-commerce yang dapat diakses di www.gypsumnatural.com, Implementasi Technopreneurship Based Curicullum pada situs ini bermanfaat untuk memberikan alternatif marketing melalui bidang Teknologi Informasi, memberikan kemudahan komunikasi, dan memperluas akses untuk membangun networking dunia bisnis.

Kata kunci : e-commerce, Technopreneurship, Content Management System, Website

\section{PENDAHULUAN}

Usaha kerajinan Gypsum belum banyak berkembang di Daerah Istimewa Yogyakarta meskipun kebutuhan masyarakat untuk menggunakan gypsum sebagai hiasan interior rumah saat ini mengalami trend peningkatan. Menurut hasil data potensi UKM dari Dinas Perindustrian dan Perdagangan Koperasi DIY tahun 2010 menunjukkan bahawa jumlah IKM Desain sebanyak 11, Fesyen sebanyak 675 , Komputer dan piranti lunak sebanyak 76 , pernainan interaktif sebanyak 5, dan terbesar adalah kerajinan sebanyak 2.236 IKM. Penyebaran usaha IKM di provinsi DIY berdasarkan wilayah kabupaten dan kota tersebar sebanyak 5 kabupaten dan 1 kotamadya dengan jumlah sebaran yaitu Kab. Bantul sebanyak 908 unit, Kab. Gunung Kidul sebanyak 478 unit, Kab. Kulonprogo sebanyak 553, Kab. Sleman sebanyak 481 unit, dan terbesar di Kota Yogyakarta sebanyak 603 unit usaha IKM. IKM yang terdata di Disperindagkop DIY terutama dari sektor kerajinan dengan jumlah terbanyak setelah ditelusuri tidak ditemukan industri/ kelompok usaha berjenis Gypsum baik di masing-masing kabupaten. Hal ini menunjukkan bahwa masyarakat yang menggeluti usaha Gypsum masih sangat sedikit, dan apabila ada maka masih berskala kecil bahkan belum memiliki ijin sehingga belum terdaftar di Disperindagkop, padahal kebutuhan masyarakat akan ketersediaan Gypsum semakin meningkat. Kebutuhan Masyarakat yang besar sementara jumlah kelompok usaha Gypusm sedikit menjadi gap dan memunculkan sebuah peluang usaha yang berpotensi besar, penting dan layak untuk dikembangkan.

Hasil wawancara yang dilakukan penyusun dengan para pengrajin Gypsum mengungkap bahwa sebenarnya Gypsum mulai banyak digemari masyarkat, hal ini dibuktikan dengan jumlah pesanan dan proyek pengerjaan Gypsum yang terus mengalami peningkatanr. Gaya hidup masyarakat mengalami perubahan yang dahulu menganggap Gypsum merupakan barang mewah dan hanya terjangkau oleh kalangan menengah keatas sekarang sudah banyak dinikmati oleh masyarakat menengah kebawah. Masyarakat umum periode sekarang memiliki keminatan menggunakan Gypsum sebagai hiasan untuk memperindah rumah mereka. Masyarakat yang menggunakan Gypsum dirumah mereka memberikan alasan menggunakan gypsum, yaitu : Gypsum memberikan kesan bersih dan rapi, Gypsum memberikan suasana dingin/adem, Gypsum murah dan Gypsum memberikan nuansa mewah/prestise. Usaha kerajinan Gypsum menjadi sebuah peluang yang memiliki potensi besar untuk berkembang dengan banyaknya pangsa pasar yang bisa dijangkau, hal ini tentu saja mesti dibarengi dengan kemampuan produksi dan kemampuan manajemen usaha yang baik.

UKM Mandiri Gypsum merupakan usaha kerajinan Gypsum yang dimiliki oleh Bp. Saroso yang beralamat usaha di Dusun Krikilan Desa Jogotirto Kecamatan Berbah Kabupaten Sleman Yogyakarta. Usaha UKM Mandiri Gypsum terdiri dari 5 anggota sebagai tenaga kerja yang diambil dari keluarga dan kerabat dekat, usaha ini mulai dirintis tahun 2009 dengan hanya bermodal 1 juta rupiah hasil dari hutang kepada orang yang selanjutnya digunakan untuk menyewa tempat usaha, tepatnya di Dusun Munggur di tepi jalan Raya piyungan-prambanan, adapun tempat usaha yang sekarang merupakan perpindahan dari tempat pertama setelah masa kontrak selesai. Bp Saroso merupakan orang yang tekun dan gigih memperjuangkan 
keberlangsungan usahanya meski harus bersaing dengan usaha-usaha Gypsum yang telah lebih dahulu berdiri. Di wilayah Desa Srimartani tempat dia tinggal terdapat 5 Kelompok Usaha Gypsum yang menjadi partner sekaligus saingan usaha. Semangat untuk pantang menyerah dan terus belajar memperbaiki kekurangan-kekurangan yang dimiliki mengubah kondisi usaha sedikit demi sedikit mulai mengalami peningkatan. Pesanan sudah mulai berdatangan baik dari wilayah sekitar maupaun dari luar, walau masih sebatas daerah di kecamatan Piyungan tempat dahulu memulai usaha. Bp Saroso menggeluti usaha Gypsum ini mulai dari nol (0), nol dalam berbagai hal, seperti ketiadaan modal, kekurangan peralatan, bahkan kemampuan membuat Gypsum pun baru dipelajari bersamaan dengan ia membuka usaha UKM Mandiri Gypsum ini. Modal utama yang dibawa oleh Bp Saroso hanyalah niat dan tekad untuk terus belajar, bekerja, pantang menyerah dan berani menghadapi resiko apapun yang dihadapi.

Tekad yang kuat telah membawanya belajar dari banyak hal termasuk kegagalan kegalalan itu sendiri. Introspeksi, evaluasi, dan mengambil pelajaran akhirnya membuahkan pengalaman dan ilmu untuk membuat Gypsum yang berkualitas. Bp Saroso mulai menerima pesanan dan pengerjaan proyek pemasangan Gypsum baik di rumah, perumahan, tempat ibadah dan lain sebagainya. Hasil pengerjaan proyek Gypsum digunakan untuk menambah peralatan dan membeli kebutuhan bahan baku disamping juga untuk mencukupi kebutuhan sehari-hari. Usaha yang dirintis oleh Bp. Saroso ini mengalami pasang surut dan berbagai problema selama perjalanan usahanya. Hal ini dikarenakan keterbatasan peralatan, bahan, sarana prasarana serta alat angkut menyebabkan tidak semua pesanan yang diterima dapat tertangani. Keterbatasan hasil produk Gypsum dalam bentuk yang sudah jadi dan siap pasang menyebabkan pesanan tidak langsung bisa dikerjakan, solusi yang selama ini dilakukan adalah dengan membeli dengan cara berhutang barang dari pengrajin lain. Sedikitnya variasi motif desain Gypsum yang dimiliki juga menjadi Kendala dalam usaha, hal ini menyebabkan konsumen tidak memiliki alternative pilihan yang puas untuk dibeli, bahkan tidak sedikit pembeli yang memilih berpindah ke Toko lain yang lebih komplit dan siap pakai.

Toko usaha Gypsum UKM Mandiri Gypsum tidak selalu buka namun terkadang tutup dikarenakan salah satunya adalah kondisi sepi pesanan, sehingga untuk mencukupi kebutuhan hidup keluarga waktu selama belum ada pesanan digunakan untuk menjadi buruh bangunan. Toko tutup juga terkadang dikarenakan sedang berbarengan dalam mengerjakan pemasangan Gypsum dirumah konsumen, sementara tidak ada yang menunggu sehingga toko mesti tutup. Tutupnya toko membawa pengaruh pada ketiadaan pesanan selama waktu pemasangan tersebut dan mengecewakan konsumen yang datang ke Toko. Promosi usaha selama ini hanya dengan mengandalkan orang atau pengguna jalan yang melihat ketika melintas di jalan melewati Toko.

Berdasarkan latar belakang yang diuraiakan diatas, permasalahan yang dihadapi cukup banyak namun dalam penelitian ini yang akan diselesaikan adalah bagaimana mengembangkan sebuah media marketing yang dapat memperkenalkan Gypsum ke masyarakat yang imbasnya akan meningkatkan penjualan dan produktivitas industri gypsum sehingga mampu menyelesaikan permasalah yang lain. Tujuan yang hendak dicapai dalam penelitian ini adalah Perancangan situs e-commerce bagi UKM Gyspum, Pengenalan Teknologi website sebagai implemetasi penerapan Technopreneurship dalam bisnis berbasis ICT sebagai media marketing dan komunikasi Antara Industri dan Konsomen, dan Menjembatani dunia industri dan akademisi.

\section{LANDASAN TEORI}

UPN "Veteran" Yogyakarta telah menetapkan Technopreneurship sebagai Matakuliah yang harus ditempuh oleh mahasiswanya. Technopreneurship merupakan sebuah inkubator bisnis berbasis teknologi, yang memiliki wawasan untuk menumbuh kembangkan jiwa kewirausahaan di kalangan generasi muda, khususnya mahasiswa sebagai peserta didik dan merupakan salah satu strategi terobosan baru untuk mensiasati masalah pengangguran intelektual yang semakin meningkat. Dengan menjadi seorang usahawan terdidik, generasi muda, khususnya mahasiswa akan berperan sebagai salah satu motor penggerak perekonomian melalui penciptaan lapangan-lapangan kerja baru. Harapan munculnya generasi Technopreneurship dapat memberikan solusi atas permasalahan jumlah pengangguran intelektual yang ada saat ini. Selain itu juga bisa menjadi arena untuk meningkatkan kualitas SDM dalam penguasaan IPTEK, sehingga mendukung mempersiapkan tenaga handal ditengah kompetisi global.Menurut Ari (2010), Manusia bergerak dari satu ekonomi ke ekonomi yang lain, keunggulan kompetitif juga mengalami perubahan paradigma, bisnis yang ingin terus bertahan 
dan maju harus memiliki value creation yaitu menciptakan sesuatu yang dianggap bernilai pada saat itu. Perubahan ini membutuhkan teknologi yang berperan sebagai : alat bantu, alat enabler, dan alat transformasi. Perubahan costumer value dan teknologi akibat perkembangan produk/ jasa berbasis teknologi merupakan bussines model implication. Contoh sederhana adalah perkembangan teknologi pada teknologi ensiklopedia yang dahulu menggunakan teknologi alphabet sekarang sudah bertransformasi/ berpindah menggunakan jaringan internet (web browser, HTML, mobile web, search engine, Slashdot postings dll. Teknologi komunikasi dan informasi atau teknologi telematika (Information and communication technology-ICT) telah diakui dunia sebagai salah satu sarana dan prasarana utama untuk mengatasi masalahmasalah aktual serta menjembatani penemuan - penemuan masa depan. Teknologi telematika dikenal sebagai konvergensi dari teknologi komunikasi (communication), pengolahan (computing) dan informasi (information) yang diseminasikan mempergunakan sarana multimedia.

Dunia akademisi saat ini menyadari pentingnya membekali mahasiswanya dengan kemampuan wirausaha sebagai tolak ukur yang paling tepat dan diyakini sekarang sebagai salah satu indikator ukuran penguasaan materi lulusan perguruan tinggi yang menggambarkan seorang mahasiswa mampu mandiri dan menciptakan lapangan kerja sendiri dan tidak berbondong-bondong melamar atau bekerja untuk orang lain, disamping itu hal ini untuk menunjukkan negera kita semakin maju berkembang diukur dari semakin besarnya warganya yang menjadi pengusaha. Kuriikulum Pendidikan Technopreneurship yang diberikan di perguruan tinggi bertujuan untuk mengatasi masalah pengangguran intelektual di Indonesia, menumbuhkan jiwa kewirausahaan dan menjembatani teori bisnis di perkuliahan dan dunia industry.

Pendidikan technopreneurship di Perguruan Tinggi sangat bermanfaat bagi mahasiswa dalam rangka memberikan alternative profesi yang dapat ditekuni setelu lulus kuliah, memperkenalkan kemampuan teknologi dalam menyelesaiakan permasalahan bisnis, memberikan pengalaman kerja dilapangan, dan juga mempernalkan jaringan mitra bisnis. Sedangkan Manfaat bagi Perguruan Tinggi sebagai fasilitator penyelenggara Matakuliah Technopreneurship adalah :

a Menjadi bentuk tanggungjawab sosial sebagai lembaga pendidikan untuk berkontribusi dalam mengatasi masalah pengangguran.

b Menjadi bagian penting dalam upaya menjembatani gap kurikulum pendidikan antara lembaga pendidikan dan industri pengguna.

c Menjadi salah satu strategi efektif untuk meningkatkan mutu lulusan.

d Menjadi wahana interaksi untuk komunitas Perguruan Tinggi yang terdiri dari alumni, mahasiswa, dosen, dan karyawan dengan masyarakat umum.

Berdasarkan tujuan tersebut di atas, maka Program Pengembangan Budaya Technopreneurship di UPN "Veteran" Yogyakarta khususnya di Jurusan Teknik Industri sudah semestinya dirancang meliputi 6 (enam) kegiatan yang saling terkait dan mendukung yaitu meliputi pelatihan materi "Techno SKILL BASED", magang kewirausahaan, kuliah kewirausahaan, kuliah kerja usaha, karya alternatif mahasiswa, dan konsultasi bisnis dan peluang usaha. Penelitian ini dimaksudkan untuk memenuhi keenam komponen tersebut diatas sehingga menjadi media pembelajaran yang efektif untuk mengenalkan dan praktek Technopreneurship di lingkungan UPN "Veteran" Yogyakarta.

Pengertian Electronic Commerce (E-Commerce) adalah proses transaksi pembelian dan penjualan produk, baik dalam bentuk jasa maupun informasi yang dilakukan secara elektronik memanfaatkan komunikasi komputer, dan salah satu jaringan yang digunakan adalah internet atau berbasis website. Organisasi Perdagangan Internasional (World Trade Organization/WTO) juga memberikan paparan E-commerce adalah produksi, iklan, jual-beli, pengalihan produk/jasa melalui rangkaian telekomunikasi tanpa batas secara Online (internet). Perusahaan Microsoft Coorporation yang mendefinisikan E-commerce sebagai suatu pertukaran barang atau jasa yang memiliki nilai menggunakan teknologi Internet.

Media elektronik yang sering dipakai adalah internet. Pemanfaatan internet dipilih karena kemudahan-kemudahan yang dimiliki yaitu Internet sebagai jaringan publik yang sangat besar (huge/widespread network), murah, cepat dan kemudahan akses, dan menggunakan data elektronik sebagai media penyampaian pesan/data sehingga dapat dilakukan pengiriman dan penerimaan informasi secara mudah dan ringkas, baik dalam bentuk data elektronik analog maupun digital. Para pihak yang melakukan kegiatan 
perdagangan/perniagaan e-commerce hanya berhubungan melalui suatu jaringan publik. Perberbedaan dengan transaksi biasa, e-commerce memiliki karakteristik yang sangat khusus, di antaranya transaksi tanpa batas, transaksi anonym, produk digital dan non digital, serta produk barang yang dijual tak berwujud. Dalam hal transformasi organisasi, e-commerce mengubah karakteristik pekerjaan, karir, dan kompensasi. E-commerce menuntut kompetensi, komitmen, kreativitas, dan fleksibilitas karyawan dalam beradaptasi dengan setiap perubahan lingkungan yang ramping; bercirikan pemberdayaan dan desentralisasi wewenang, beranggotakan knowledge based workers; mampu beradaptasi secara cepat dengan teknologi baru dan perubahan lingkungan (learning organisation); mampu dan berani bereksperimen dengan produk, jasa, maupun proses baru; dan mampu mengelola perubahan secara strategik. Sedangkan dalam hal redefinisi organisasi, e-commerce memunculkan model bisnis baru yang berbasis jasa Online di marketspace. Hal ini dapat berdampak pada redefinisi misi organisasi dan cara organisasi menjalankan bisnisnya. Perubahan ini antara lain meliputi peralihan dari sistem produksi massal menjadi manufaktur just in time (JIT), integrasi berbagai sistem fungsional (seperti produksi, keuangan, pemasaran, dan sumber daya manusia). Sistem e-commerce memiliki lima subsistem umum, yaitu: Inventory Management System, Profile Management System, Ordering Management System, Shipping/Delivery Management System dan Reporting System Pengertian Content Management System (CMS) atau sering disebut dengan CMS adalah aplikasi web yang berbentuk template untuk mengelola isi web secara mudah. Content Management System tidak memerlukan pengetahuan pemrograman web yang handal karena proses instalasi dan cara penggunaannya sudah user friendly. CMS sendiri ada yang dirancang khusus menyesuaikan kasus yang ada dan biasanya berbayar dan ada yang berupa template instan yang fungsionalitasnya dibuat dengan menyesuaikan pada beberapa proses bisnis yang ada didunia nyata yang dapat digunakan secara gratis. Aplikasi Content Management System instant yang banyak terdapat di internet saat ini kebanyakan dibuat menggunakan scripting language PHP dan database-nya adalah MySQL. Saat ini perkembangan Content Management System cukup pesat, banyak vendor yang membuat CMS instant yang didistribusikan secara gratis. Perkembangan CMS instant ini juga dipicu oleh perkembangan web 2.0 yang memungkinkan interaksi dalam arti yang cukup luas antara pengelola web dan pengunjung web.

Perkembangan pesat Content Management System juga diperkuat oleh kebutuhan masyarakat dan pelaku bisnis yang menginginkan web dapat mendukung kegiatan bisnis mereka secara mudah terutama dalam bidang pengelolaan content, cepat dalam pembuatan web, serta murah dalam pengadaannya. Era saat ini, pengembangan aplikasi web CMS sudah banyak yang menggunakan konsep framework. dengan konsep ini, dimungkinkan memodifikasi fitur Content Management System secara instan karena semua dirancang berbentuk modular. Dari uraian pengertian CMS tersebut maka CMS memiliki fungsi :

\section{Content Making}

Pembuatan content berita, informasi dan sebagainya dilingkungan CMS adalah mudah, karena bisa dilakukan oleh siapapun tanpa harus mengetahui dasar HTML. Kebanyakan CMS sekarang penulisan contentnya dikembangkan dilingkungan berbasis web, dengan implementasi yang lebih sederhana serta mengijinkan untuk diupdate tanpa harus menghapus dulu.

2. Content Management

Satu halaman telah dibuat, maka CMS akan menyimpan halaman tersebut pada tempat penyimpananya. Semuanya disimpan dengan link yang terkait. Pusat penyimpanan juga menyediakan fasilitas untuk mengelola content dengan metode : menjaga traking semua content sehingga bisa mengerahui siapa merubah dan kapan, memastikan masing-masing user hanya punya privasi sesuai dengan haknya, mengintegrasikan dengan system sesuai dengan spesifik kontent tersebut, dan yang paling penting adalah masalah workflow capability.

3. Publication

Setelah atikel di terima oleh admin dan direview, tentunya disini admin atau user lain yang biberi privelege juga berhak untuk mengedit kali dirasa semua sudah sesuai 
selanjutnya artikel tersebut akan diapprove maka secara otamatis akan dipublikasikan sesuai dengan kategorinya.

4. Presentation

CMS dapat juga menyediakan penomeran atau berdasar tanggal untuk memindah kualitas dan efektifitas dirinya,sebagai contoh CMS akan membangun navigasi buat kita dengan membaca struktur pengeluaran yang urut dari content yang telah disimpannya. Sehingga akan membantu dalam mempresentasikan

Joomla adalah salah satu CMS Opensource yang didesain untuk dapat digunakan multi scope. mulai dari yang sederhana sampai yang kompleks, bahkan sampai ke level corporate. joomla mudah dalam pengintallan, sederhana dalam memanage dan reliable. Joomla adalah pionir dan terunggul untuk kategori CMS, yang mana akan membantu kita dalam membuat website atau aplikasi online lainya. lebih dari Joomla adalah aplikasi yang opensource gratis yang didesain untuk semua. Joomla digunakan diseluruh dunia, diantaranya Joomla digunakan untuk : Corporate websites or portals, Online commerce, Small business websites, Non-profit and organizational websites, Government applications, Corporate intranets and extranets, School and church websites, Personal or family homepages, Community-based portals, Magazines and newspapers, the possibilities are limitless. Joomla adalah salah satu aplikasi yang digunakan untuk membuat atau membangun sebuah website dinamis yang dilengkapi berbagai fasilitas yang mendukungnya.

Joomla dapat dengan mudah dirawat, mulai dari penambahan content, update katalok produk atau pemesanannya. Tampilan template untuk mengelola content mirip dengan tampilan office word sehingga mudah untuk dipahami. Joomla didesain untuk mudah di install, bahkan oleh orang yang bukan programmer. kebanyakan orang tidak kesusahan dalam mendapatkan Joomla dan menjalankannya, serta banyaknya support komunitas. Komunitas Joomla lebih dari 40.000 baik yang sebagai pengguna ataupun developernya. Joomla menawarkan berbagai kemudahan dan fleksibilitas untuk penggunanya. Fitur - fitur di CMS Joomla disesuaikan dengan e-commerce yang dirancang. Berikut ini beberapa kelebihan Joomla yaitu :

1. Joomla adalah opensource artinya joomla bisa digunakan secara gratis. Website joomla bisa didownload secara gratis. Orang masih harus membayar untuk layanan webhosting Indonesia.

2. Joomla mudah dijalankan bahkan oleh pemula sekalipun. Ketika merancang website $E$ commerce hanya perlu berhadapan dengan user interface CMS ini. Tidak perlu repotrepot mempelajari bahasa pemrograman yang rumit. Joomla memang dirancang untuk pengguna awam, tetapi para expert pun tidak segan menggunakannya.

3. Joomla Hosting adalah pilihan yang sangat fleksibel. Anda bisa merancang website Anda sendiri mulai dari nol. Ada banyak pilihan template dan fitur yang tersedia.

Technopreneurship merupakan istilah lain dari wirausaha berbasis teknologi, sehingga kata kunci utamanya tetap wirausaha. Wirausaha adalah sebuah proses perdagangan atau jual beli berarti harus ada yang diperjualbelikan agar terjadi proses transaksi untuk mengalirkan uang dari pembeli/konsumen ke penjual atau produsen. Profit atau keuntungan yang diperoleh tergantung dari seberapa besar produk yang ditawarkan dapat memikat daya minat konsumen untuk membeli produk. Aplikasi Technopreneurship dalam dunia Bisnis tentu saja menyesuaikan dengan keadaan dan konsisi industri yang akan diaplikasikan prinsip technopreneurship ini. Hal tersebut bertujuan untuk menghindari terjadinya salah sasaran, ketidakberkembangan, dan bahkan memperlambat kegiatan bisnis yang sudah berjalan. Pengkajian awal terhadap kondisi dan kemampuan UKM Mandiri Gypsum dilakukan untuk mendapatkan road map yang jelas tentang teknologi yang akan diterapkan dalam industri ini. Kebutuhan setiap industri terhadap teknologi jelas berbeda, peralatan yang kompleks jika tidak sesuai malah dapat mengakibatkan ketidakefisienan dalam bekerja dikarenakan pemborosan dalam berbagai bidang.

\section{METODE PENELITIAN}

Pendekatan yang dipergunakan dalam penelitian ini adalah dengan metode System Development Life Cycle (SDLC), pendekatan sistematis untuk merancang/ merencanakan, mendesain, mengimpelementasikan serta evaluasi suatu sistem. Tahapan-tahapan dalam pendekatan $S D L C$ adalah sebagai berikut: 


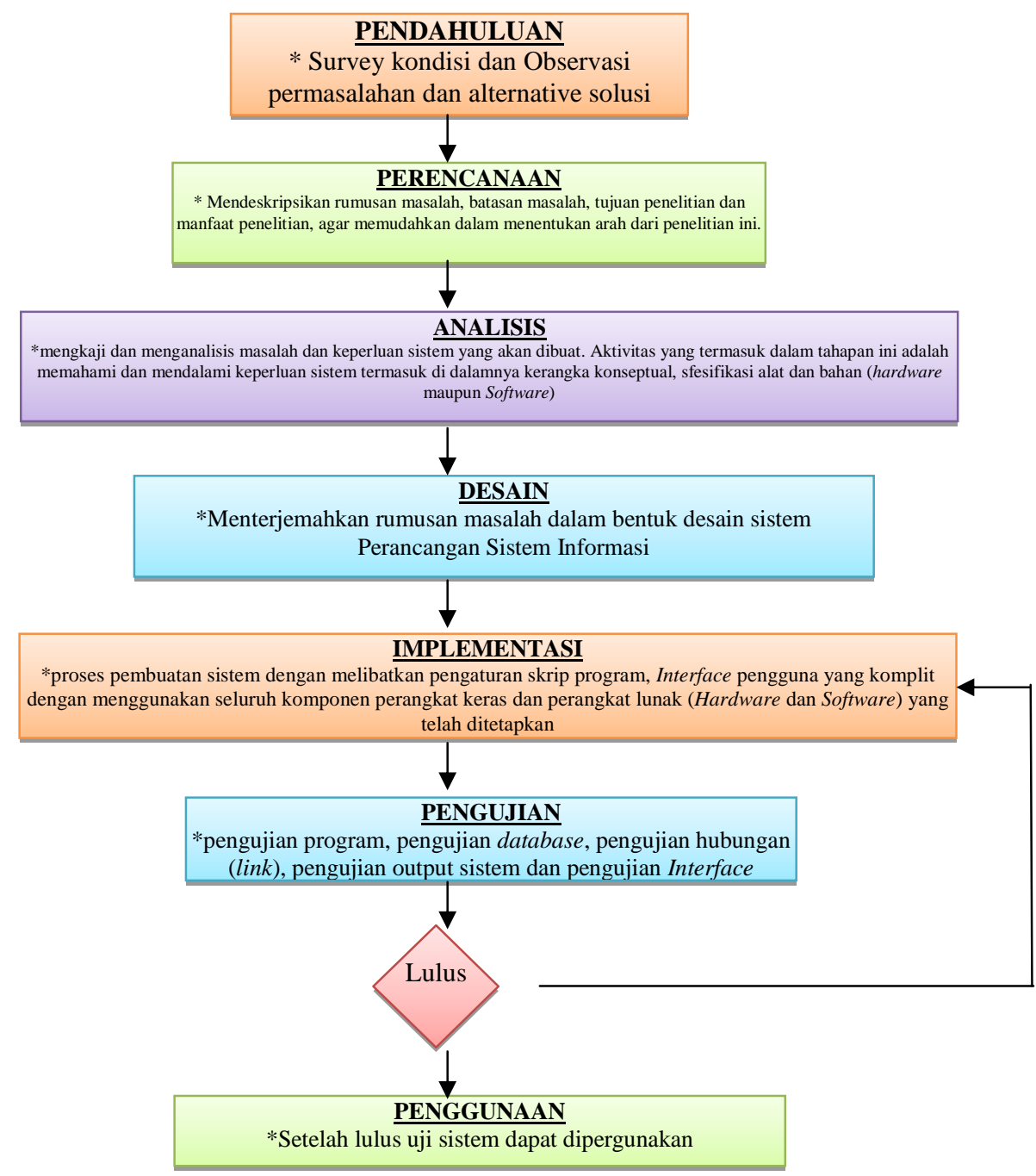

Gambar 1. Langkah Penelitian

Website UKM Mandiri Gypsum dirancang agar dapat saling terjadi interaksi antara berbagai komponen yang terlibat dan saling mendukung untuk menciptakan kesatuan alur proses bisnis yang sistematis

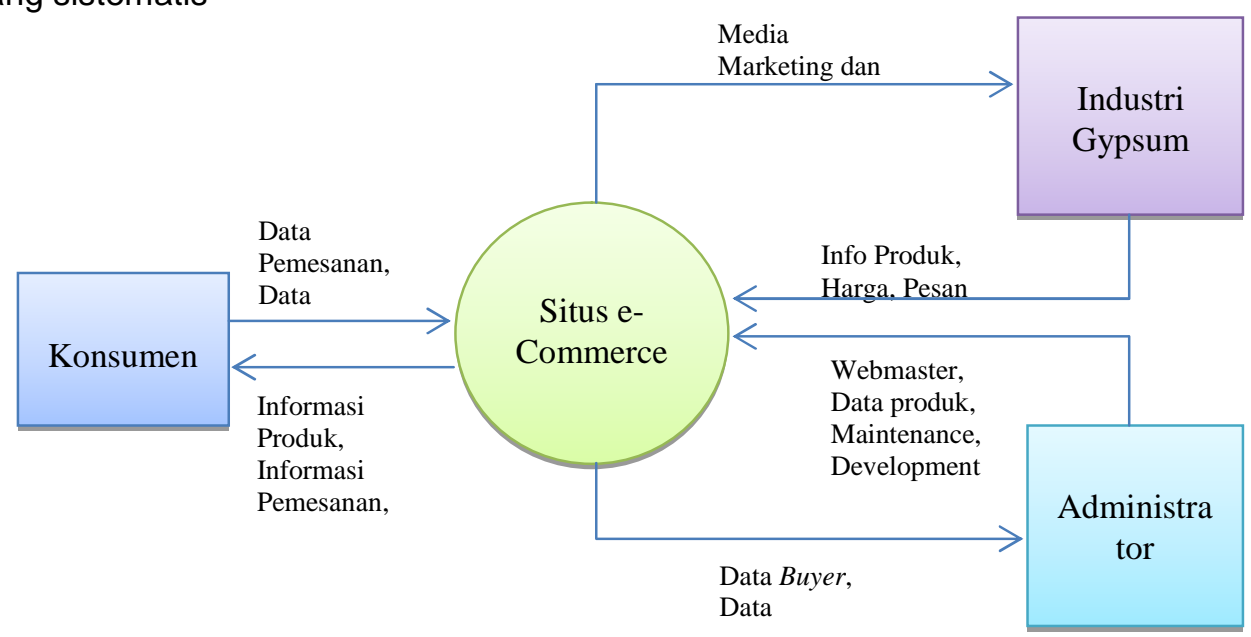

Gambar 2. Diagram Konteks Situs e-commerce AutoDuplicated 
UKM Mandiri Gypsum saat ini membutuhkan media promosi dan memperkenalkan produk yang mereka produksi agar lebih dikenal oleh masyarakat luas, selain itu juga untuk mengatasi permasalahan kekosongan toko akibat ditinggal oleh si pemilik ketika sedang mengerjakan pekerjaan diluar, menghindari kekecawaan konsumen yang datang namun tidak dapat bertransaksi, menyediakan media untuk menampilkan berbagai produk olahan serta variasi gypsum agar memberikan pilihan alternatif yang banyak bagi konsumen untuk memilih. Berdasarkan kajian diatas maka perlu dirancang website yang mampu menyelesaikan permasalahan tersebut, mengingat si pemilik toko tidak memiliki pengetahuan yang cukup tentang dunia website maka dipilihlah mesin pembuat website yang mudah dioperasikan namun handal dan teruji, yaitu CMS Joomla.

Pengelola website mampu menampilkan produk - produk dan variasi Gypsum di website serta memberikan deskripsinya. Konsumen dapat memilih dengan leluasa dan melihat foto - foto desain yang cocok untuk interior eksterior rumahnya sebelum melakukan transaksi pembayaran. Berikut desain tampilan website UKM Mandiri Gypsum

\begin{tabular}{|l|l|l|l|l|l|l|}
\hline \multicolumn{6}{|c|}{ HEADER } \\
\hline Home & Profil & $\begin{array}{c}\text { Desain } \\
\text { Interior }\end{array}$ & $\begin{array}{c}\text { Variasi } \\
\text { Gypsum }\end{array}$ & $\begin{array}{c}\text { List } \\
\text { Produk }\end{array}$ & Pesan & Cari \\
\hline \multicolumn{6}{c}{ CONTENT WEBSITE } \\
\hline
\end{tabular}

Gambar 3. Tampilan Menu Website

Web website UKM Mandiri Gypsum pada halaman utama yang diakses oleh publik dirancang dengan tampilan user Interface seperti diatas untuk memudahkan pengunjung dalam mengeksplorasi isi dan memahami maksud dari web ini. Fungsi menu - menu dalam rancangan website diatas adalah sebagai berikut :

Home berfungsi untuk menampilkan halaman depan

Profil berfungsi untuk menampilkan profil UKM Mandiri Gypsum

Desain Interior berfungsi untuk menampilkan informasi tentang desain interior rumah

Variasi Gypsum berfungsi untuk menampilkan gambar atau foto variasi produk - produk gypsum

List Produk berfungsi untuk menampilkan gambar atau foto macam - macam list gyspum

Pesan berfungsi untuk menampilkan informasi kontak dan alamat yang dapat dihubungi

Cari berfungsi untuk memberikan fasilitas pencarian konsumen berdasarkan keyword yang dikehendaki

\section{HASIL DAN PEMBAHASAN}

Website Technopreneurship e-commerce UKM Mandiri Gypsum adalah sebuah media wirausaha berbasis teknologi yang menjadi sarana marketing dan komunikasi untuk menghasikan transaksi jual beli antara penjual dan pembeli yang dirancang untuk mampu menampilkan keunggulan ciri khas produk gypsum beserta variasi list yang diharapkan mampu memikat konsumen untuk memesan. Perancangan website disamping untuk kepentingan marketing memiliki keunggulan utama yaitu online 24 jam sehari nonstop yang tidak dimiliki oleh toko - toko konvensional yang buka berdasarkan jam kerja.

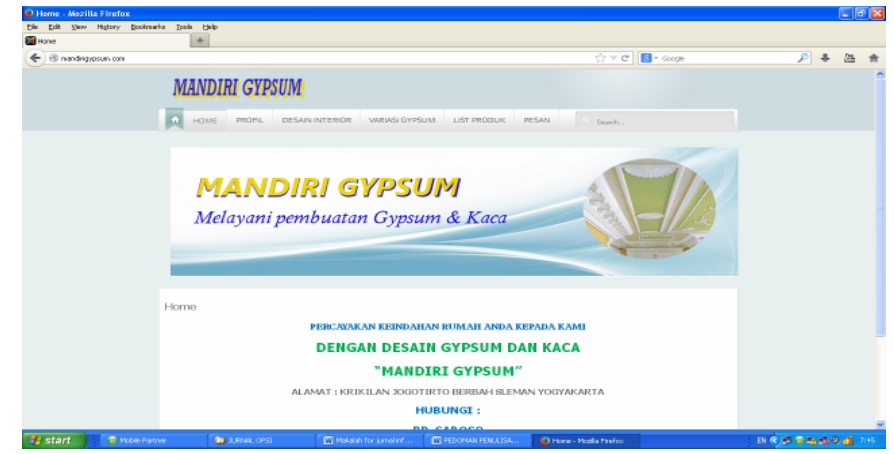

Gambar 4. Tampilan Halaman Depan 
Halaman depan website UKM Mandiri Gypsum yang pertama kali akan tampil setelah pengunjung mengetikkan dan mengklik alamat domain UKM Mandiri Gypsum

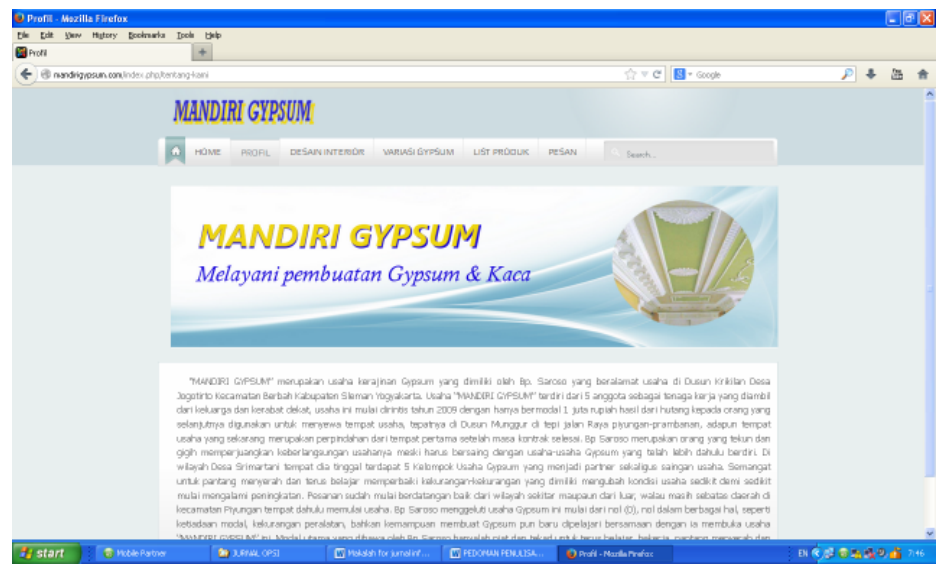

Gambar 5. Tampilan Menu Profil

Halaman profil website UKM Mandiri Gypsum berisi profil UKM Mandiri Gypsum mengenai sejarah dan perkembangannya.

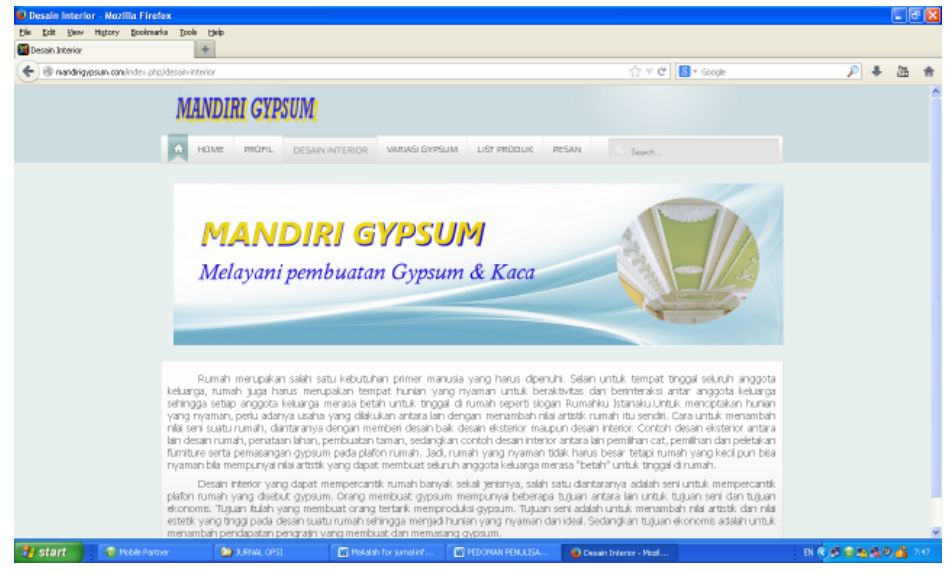

Gambar 6. Tampilan Menu Desain Interior

Halaman Desain Interior website UKM Mandiri Gypsum menunjukkan informasi dan pengetahuan sekilas bagi pengunjung tentang desain sebagai bekal pengetahuan untuk menentukan tipe dan jenis gypsum yang sesuai untuk dipesan.

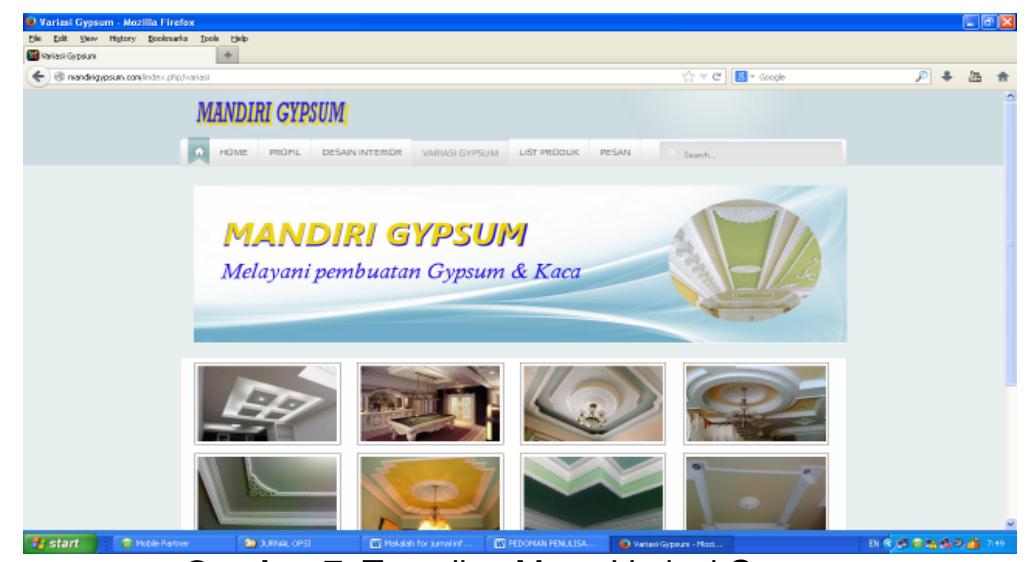

Gambar 7. Tampilan Menu Variasi Gypsum 
Halaman Variasi Gypsum website UKM Mandiri Gypsum menunjukkan berbagai foto dan gambar variasi produk gypsum yang terpasang secara indah dan menarik untuk memberikan inspirasi dan desain yang menarik bagi konsumen.



Gambar 8. Tampilan Menu List Produk

Halaman List Produk website UKM Mandiri Gypsum menunjukkan berbagai foto dan gambar berbagai macam jenis list gypsum yang indah dan kreatif untuk memberikan inspirasi dan desain yang menarik bagi konsumen.

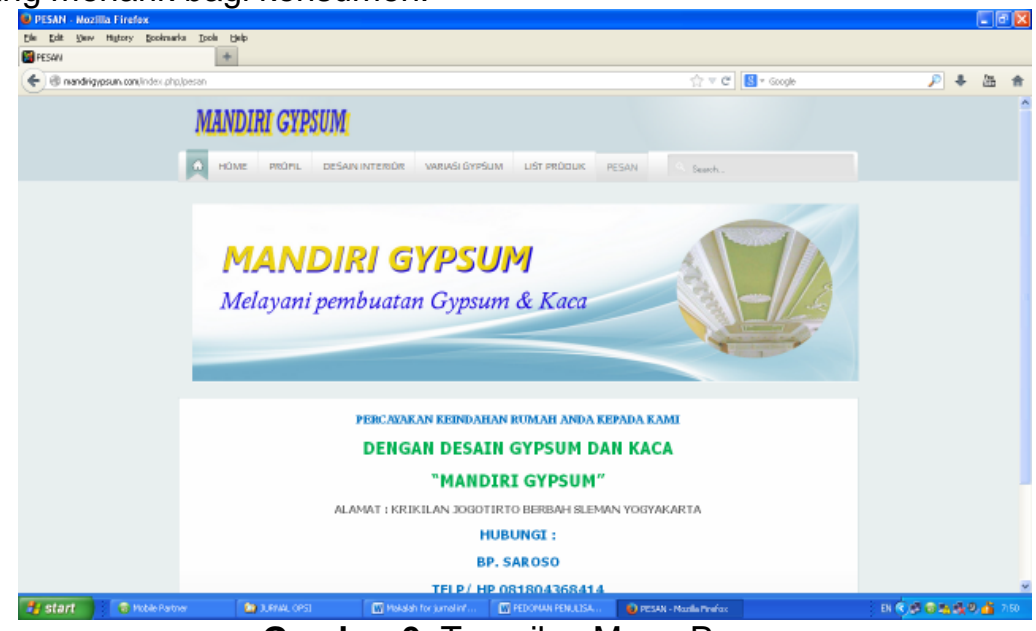

Gambar 9. Tampilan Menu Pesan

Halaman menu pesan memberikan informasi kontak dan alamat yang dapat dihubungi oleh konsumen apabila ingin melakukan pemesanan. Menu pesan didesain sederhana dan tidak menggunakan interaktif online mengingat keterbatasan kemampuan agar pemilik UKM tidak pusing memikirkan maintenance website dan menghindari pemilik UKM terlalu sibuk dengan website sehingga pekerjaan utama terbengkalai.

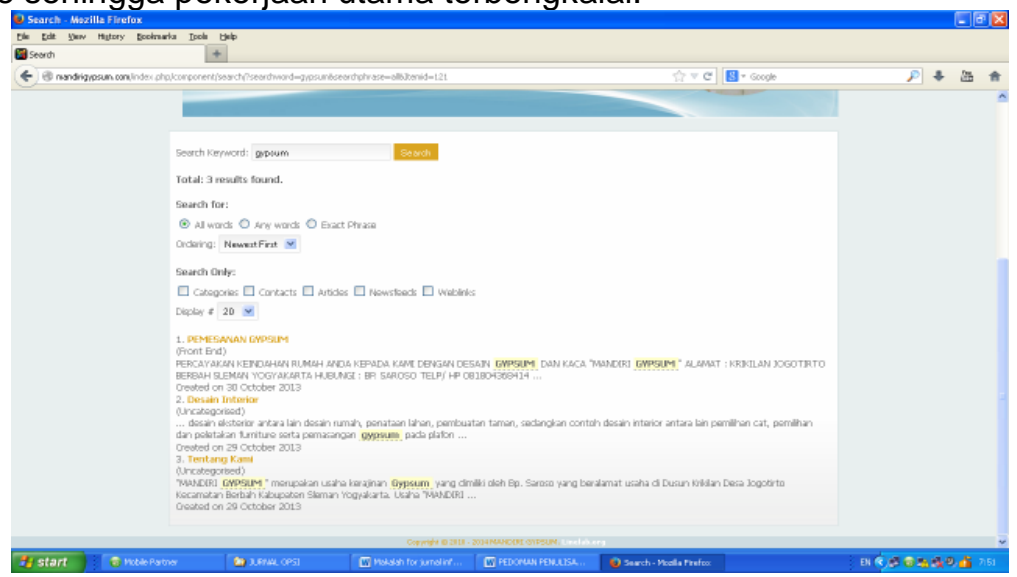

Gambar 10. Tampilan Menu Cari 
Halaman cara merupakan modul tambahan yang dipasang didalam website untuk memudahkan konsumen mencari informasi yang dikehendaki dengan mengetikkan kata - kata kunci pada form yang disediakan.

Penulis menentukan nama website sekaligus menjadi nama untuk alamat URL atau domainnya dengan dengan alamat URL adalah www.mandirigyspum.com dengan mempertimbangkan kesesuaian nama, jenis usaha, kemudahan mengingat, dan familier. Penentuan hosting dalam pembuatan website ini penulis menseleksi dengan beberapa kemampuan yang memungkinkan script dapat berjalan dengan baik tanpa ada halangan atau kendala terkait ke-compatible-an serta beberapat perangkat/tools/software pendukung yang ada didalamnya, hal ini juga terkait dengan kapasitas, kecepatan akses, lokasi server, kehandalan, tingkat kredibilitas penyedia layanan Hosting, dan pengalaman.

Hasil pengujian dan simulasi website UKM Mandiri Gypsum yang beralamat di www.mandirigypsum.com telah dapat diakses secara Online dan pengujian program menunjukkan sistem dapat berjalan dengan baik sesuai dengan fungsinya. Sistem Informasi berbasis website e-commerce ini dirancang untuk menjembatani aplikasi Technopreneurship di akademisi dengan dunia bisnis di lapangan khususnya di UKM Mandiri Gypsum.

\section{KESIMPULAN DAN SARAN}

Kesimpulan yang dapat dihasilkan dari penelitian ini adalah :

1. Penelitian ini telah menghasilkan situs e-commerce sebagai media aplikasi Technopreneurship bagi UKM Mandiri Gypsum yang beralamat di www.mandirigypsum.com.

2. Website yang telah dihasilkan mampu menampilkan informasi profil perusahaan, pengetahuan tentang desain gypsum, dan berbagai penawaran produk hasil olahan UKM Gypsum.

3. Website yang dihasilkan dapat menjembatani dunia akademisi dan dunis bisnis industry yang bertujuan untuk meningkatkan profit bagi UKM.

Saran penulis sebagai berikut :

1. Bagi mahasiswa, website ini dapat digunakan contoh aplikasi teknologi technopreneurship di dunia industi untuk dikembangkan dalam sector bisnis yang lain.

2. Bagi Dosen, Website ini dapat digunakan sebagai sarana untuk menunjukkan secara real penerapan Technopreneurship dalam belajar mengajar di kelas yang secara tidak langsung dapat juga digunakan untuk meningkatkan kemampuan entrepeneurship berbasis tekmologi.

3. Bagi Satker ataupun UKM, Website ini dapat dikembangkan dan disosialisasikan kepada seluruh masyarakat dan mitra bisnis untuk mendapatkan konsumen sebanyak mungkin dan perlu untuk dilakukan perancangan system yang lebih lengkap dengan tentu saja mempertimbangkan kemampuan SDM yang dimiliki juga memunculkan berbagai jenis produk lain yang dapat dipasarkan sesuai dengan situasi dan kondisi serta potensi di lingkungannya masing - masing. 


\section{DAFTAR PUSTAKA}

Donny, Edwin, 2003. Industri E-commerce Global, Jakarta: PT. Gramedia Pustaka Utama.

Eko S., Ari S., 2010 Technopreneurship: Strategi Penting dalam Bisnis Berbasis Teknologi, PT Elex Media Komputindo, Jakarta,

Hamdan, et.al., 2005. Teknologi Maklumat. Malaysia: McGraw Hill My.

Kalakota dan Whiston, 1997. E-commerce Perspective, California: The Benjamin Cummings.

Kearny, E, 2005. Potensi Untuk E-commerce Di Benua Asia. Malaysia: FTSM Publisher.

McLeod, Raymond, Management Information System, $7^{\text {th }}$ ed., Prentice Hall, New Jersey, 1998.

McNurlin, Barbara C,; Sparague, Ralph H Jr., Information Systems Management in Practice, $4^{\text {th }}$ ed., Prentice Hall, New Jersey, 1998. 